\title{
Bursa İli Tarımsal Pestisit Kullanımının Değerlendirilmesi
}

\author{
Aslihan KATİP* \\ Bursa Uludă̆ Üniversitesi Mühendislik Fakültesi Çevre Mühendisliği Bölümü, Bursa, Türkiye
}

\begin{abstract}
$\ddot{O} \mathbf{z}$
Bu çalışmada pestisit kullanımını yönetmek ve çevre kirliliğini önlemek amacıyla yapılabilecek Bütüncül Pestisit Yönetimi çalışmalarına bilgi sağlamak amaçlanmıştır. Bu çalışmada Dünya'da, Ülkemiz' de ve Bursa İlinde pestisit türlerinin kullanımı değerlendirilmiştir. Ayrıca Bursa'da kullanılan pestisit türlerinin yıllık miktarları ile tarımsal ürünler arasındaki ilişkiler istatistiksel olarak hesaplanmıştır. Bursa'daki pestisit kullanımının, Avrupa ve Türkiye'dekine benzer olduğu ve en çok tüketilen pestisit türünün fungusitler (\%59-80) en az kullanılanların Nematosid ve Mollusidler olduğu belirlenmiştir. Tarımsal üretimin nüfus ve ihracat artışı ile orantılı olduğu ancak pestisit kullanımında azalmaların olduğu görülmüştür. Bursa'da akarisit kullanımı ile tarla bitkileri arasında, fungusit ve herbisit kullanımı ile meyve üretimi arasında, sebze üretimi ile nemotosit, mollusitler, insektisit ve kışlık-yazlık yağlar arasındaki ve diğer pestisit türleri ile meyve üretimi arasındaki ilişkiler istatistiksel olarak önemli $(\mathrm{p}<0,05)$ bulunmuştur. Diğer ürünlere göre daha az üretilen meyvelerin daha fazla herbisit ve diğer pestisit türlerinin kullanımına neden olduğu belirlenmiş̧ir. Bu sonuçlar ürün cinsinin pestisit tüketimde etkili olabileceğini göstermiştir.
\end{abstract}

Anahtar kelimeler: Bütüncül Pestisit Yönetimi, Çevre Kirliliği, Tarımsal Üretim.

\section{Evaluation of Agricultural Pesticide Usage in Bursa City}

\begin{abstract}
The aim of this study was to provide information for integrated pesticide management to decrease environmental pollution and manage pesticide usage. In this study, pesticide usages in the world, our country and Bursa city were determined. Also, the statistical correlations between the annual usages of the pesticide species in Bursa and agricultural productions were determined. It was determined was pesticide usage in Bursa was similar Europe and Turkey and fungicides (59-80\%) were high consumed pesticides and nematocides and mollusicides were the lower ones. It was seen that agricultural production proportional with population and export increasing but pesticide usage in Bursa decreased. The correlations between acaricide and farm plants, between fungicide-herbicide and fruit production, between nemotocide, mollucide, insecticide and winter-cottage oils, also, other pesticide species and fruit production were significant statistically $(\mathrm{p} \leq 0,05)$. Although fruit production was less than other products it caused more herbicides and other pesticides consumption. Therefore product specie might be effective in pesticide consumption.
\end{abstract}

Keywords: Integrated Pesticide Management, Environmental Pollution, Agricultural Production.

\section{Giriş}

Dünya genelinde nüfus artışı ile birlikte sanayi bölgelerinin artması ve yeni yerleşim yerlerinin inşa edilmesi sebebiyle tarım arazisi olarak kullanılan alanlar giderek azalmaktadır. Artan nüfus tarımsal üretim üzerinde büyük bir baskı yaratmışır ve gıda ihtiyacı toprak, su, vb. gibi mevcut kaynaklardan karşılanabilmektedir. Bu nedenle verimi arttırmak amacıyla pestisit kullanımında da artışlar olmuştur $[1,2]$. Tarımsal üretimde, pestisit kullanımının $\% 60$ ile \% 70 arasında kalite ve verim artışını sağladığı, ancak fazla miktarda kullanıldığında ise ekonomik kayıplara yol açan zararlıların oluşmasına neden olduğu görülmektedir [3, 4].

\footnotetext{
"Sorumlu yazar:aballi@uludag.edu.tr

Geliş Tarihi: 10.08.2018, Kabul Tarihi: 21.11.2018.
} 
Pestisitler Birleşmiş Milletler Gıda ve Tarım Örgütü (FAO) tarafından tanımlanmıştır. Pestisitler, gıdaların, tarımsal ürünlerin, ahşap ürünlerinin veya hayvan yemlerinin üretiminden tüketimine kadar tüm aşamalarda ürünleri olumsuz etkileyen zararlıları kontrol altına almayı sağlayan, hayvanlar üzerinde veya vücutlarında bulunabilecek zararlıları kontrol altına alan maddelerdir. Ayrıca, bitki büyümesini düzenleyen, yaprak döken, kurutan, meyve seyrelten veya ham meyvelerin dökülmesini önleyici etkenleri ve depolanma ve taşınma sırasında ticari malların bozulmasını önleyen maddeler olarak tanımlanmıştır [5]. Bu tanımdan anlaşıldığı gibi pestisitler sadece tarımsal amaçlı değil, zararlıların farklı alanlarda kontrol altına alınabilmesi için de kullanılmaktadır [6]. Pestisitlerin etkiledikleri canlılara ve kullanım alanlarına göre değişen kimyasal yapıları çok farklı türleri bulunmaktadır $[5,7,8]$. Çoğunluğu sadece hedef organizmayı değil ekosisteme zararsız veya yararlı olan organizmalar1 etkilemektedir [9]. Genel olarak, pestisitlerin sadece \% 0,1'inin hedef organizmalara ulaştığı ve kalan konsantrasyonların suda ve toprakta yaşayan organizmaların besin zincirine girdiği tahmin edilmektedir $[6,10]$. Bu nedenle çevreyi kirleterek insanlarda ve diğer canlılarda akut ve kronik hastalıklara neden olmaktadırlar $[11,12]$.

Pestisitlerin kullanılan miktarları ve türü, zararlıların yaygınlığı, iklim koşulları, ülkenin gelişmişlik durumu ve yaygın ürün gibi pek çok faktöre bağlı olarak değişebilmektedir [13]. Sürdürülebilir tarımsal üretimin sağlanabilmesi ve kirliliğinin önlenerek çevre ve insan sağlı̆̆ının korunabilmesi için pestisit tüketiminin azaltılması gerekmektedir. Bütüncül Pestisit Yönetimi (IPM), zararlıların yönetilmesi amacıyla zirai mücadele, tarımsal üretim ve çevreyi bütünleşik bir şekilde ele alan etkili bir yönetim biçimidir [14]. IPM programları zararlıların yaşam döngüleri ve çevre ile etkileşimleri hakkında güncel ve kapsamlı bilgileri kullanmaktadır. Ayrıca, mevcut haşere kontrol yöntemleri ile birlikte, haşere hasarını en ekonomik yollarla insanlar, mülk ve çevre için mümkün olan en az tehlike ile yönetmektedir. Bütüncül Pestisit Yönetiminin izleme, tanımlama ve kontrol aşamasında, pestisitlerin ihtiyaç duyulup duyulmamasının belirlenmesi, yanlış türde pestisit kullanımının önlenmesi, gıda güvenliği ve ürün kaybının azaltılması, pestisit maliyetinden tasarruf edilmesi ve ihracat kriterlerine uyulması sağlanmaktadır [15].

Sabur ve Molla'nın 2001 yılında Bangladeş'te yapmış olduğu bir çalışmada [16], ürün çeşitleri içerisinde en çok sebze üretiminde pestisit tüketildiği ve muz ve mango dışındaki ürünlerde aşırı kullanım olduğu belirlenmiştir. Ayrıca Bütüncül Pestisit Yönetimini uygulayan çiftçilerin daha az pestisit tükettikleri görülmüştür. Rahman ve Chima'nın 2018 yılına yapmış oldukları bir çalışmada [17], tarımsal ürün çeşidine göre pestisit kullanımı belirlenmiştir. En çok pestisit tüketiminin Hint yer elmasında olduğu ve küçük araziye sahip çiftçilerin daha çok pestisit tükettiği belirlenmiştir. Ayrıca, pestisit kullanımının iş gücü maliyetlerinin ve ürünlerin daha pahalı olmasına yol açtığı ve eğitilen çiftçilerin daha az kullanım sağladıkları belirlenmiştir.

$\mathrm{Bu}$ çalışmada, Bursa İlinde tarımsal pestisit kullanımının azaltılabilmesi için yapılabilecek Bütüncül Pesitisit Yönetimi izleme, tanımlama ve kontrol aşamalarına bilgi sağlamak amaçlanmıştır. Bu çalışma kapsamında Dünya ve Türkiye'de kullanılan pestisit türleri ve miktarları ile Bursa'daki pestisit kullanımı karşılaştırılmıştır. Ayrıca, Bursa İli bitkisel ürün çeşidi ile kullanılan pestisit türleri arasındaki korelasyonlar istatistiksel olarak belirlenmiştir. Bu çalş̧ma bitkisel ürün çeşidine göre pestisit kullanımının belirlenmesi, tarımsal ürün maliyetlerinin azaltılması ve çevre kirliliğinin önlenebilmesi açısından önemlidir.

\section{Materyal ve Metot}

Bu çalışmada Türkiye İstatistik Kurumundan (TÜİK) alınan veriler kullanılarak 2001 ile 2015 yılları arasında Türkiye'de tüketilen toplam pestisit miktarları hesaplanmıştır [18]. Ülkemizde her yıla ait verinin olmaması sebebiyle 2006 y1lı ile 2015 yılı arasında tüketilen pestisit türleri belirlenmiştir. Hesaplanan değerler Dünya'da ve Türkiye'de coğrafi bölgelere göre kullanılan pestisit türleri ve miktarları karşılaştırılmıştır.

Ayrıca, Bursa İlinde 2009-2016 yılları arasında tarımsal amaçlı kullanılan pestisit türleri ve miktarları hesaplanmıştır. Buna ilaveten 2008-2016 yılları arasında üretilen tarımsal ürün çeşidi ve miktarları belirlenmiştir. Ürünlerin ve kullanılan pestisitlerin çok çeşitli olması sebebi ile ürün çeşitleri, meyve, sebze ve tarla bitkileri olarak, pestisitler akarisit, fungusit, herbisit, kışl1k ve yazlık yağlar, nematosit ve mollusitler, rodendisit ve mollusitler, insektisitler ve diğerleri şeklinde gruplandırılarak toplam değerleri yıllar bazında hesaplanmıştır. Aynı yıllara ait pestisit türü ve miktarları ile İldeki 
bitkisel üretim çeşidi korelasyon analizi ile istatistiksel olarak ilişkilendirilmiştir [19]. Kullanılan veriler Bursa İl Gıda, Tarım ve Hayvancılık Müdürlüğü'nün Faaliyet Raporlarından sağlanmıştır [20].

\section{Bulgular ve Tartışma}

\subsection{Dünya ve Türkiye'de Pestisit Kullanımı}

Pestisitlerin Dünya'da kullanımı, ülkelerin gelişmişliğine, iklimsel şartlara, zararlıların prevalansına, yetiştirilen tarımsal ürüne ve miktarlarına bağlı olarak değişmektedir [13]. Dünya genelinde pestisit kullanımlarına ait veri ve raporlar her ne kadar düzensiz ve yetersiz olsa da, tarımda sentetik pestisit kullanımının istikrarlı bir şekilde artmakta olduğu belirlenmiştir. Son yıllarda dünyada tarımsal pestisit kullanımı yaklaşık 3,5 milyon tona ulaşmıştır. Dünya pazarındaki en yüksek büyüme 1960'larda yıllık \%12 gibi bir oran ile meydana gelmiştir. Daha sonra bu oran 1980-1990'l1 yıllarda \% 2 ve daha düşük bir seviyeye inmiştir. 2014 yılında \%3'e yükselmiştir [14]. Pestisit üretimlerinin 1950'li yıllarda 0,2 milyon ton iken 2000'li yıllarda 5 milyon ton civarına çıktığı belirlenmiştir [21].

Avrupa Birliği istatistiksel raporlarına göre ülkelerin başlıca pestisit gruplarının satışları incelendiğinde, Avrupa'da en çok satışın İspanya' da (\%19,9) ve Fransa'da (\%19) olduğu görülmektedir. En az satışında, Malta ve Lüksenburg'ta (\% 0) olduğu belirlenmiştir. Avrupa Birliği Satış raporlarında, fungusit ve bakterisitlerin $\% 43,8$, herbisit ve yosun öldürücülerin $\% 33,2$, diğer bitki koruyucuların $\%$ 14,2 , insektisit ve akarsitlerin $\% 5,2$, bitki büyütme ve düzenleyicilerin $\% 3,2$ ve yumuşakçalar öldürücülerin \% 0,4 oranında tüketildiği belirlenmiştir [22]. Bu satış rakamlarından Avrupa ülkelerinde en çok satılan pestisit grubunun fungusit ve bakterisit olduğu görülmüştür. Dünya genelinde kullanılan pestisit türlerinin dağılımına bakıldığında ise \% 47,50'lik oranla herbisitler en yüksek paya sahiptir. Daha sonra \% 29,50'lik oranla insektisitler ve \%17,50'lik oranla fungusitler yer almaktadır [23]. 1990 ve 2011 yılları arasındaki verilere göre OECD ve Afrika ülkelerinde en çok herbisit ve fungusit kullanılırken, Latin Amerika ve Asya ülkelerinde herbisit, insektisit ve fungusit kullanımı daha fazladır. Ayrıca, kullanımın en çok olduğu ilk üç ülke sırasıyla, Çin, Amerika Birleşik Devletleri ve Arjantin'dir [14].

Türkiye'de 2001 ile 2015 yılları arasında en yüksek pestisit kullanımının 2001 y1lında 51210 ton olduğu görülmüştür. Bu süre içerisinde pestisit kullanımının \%23,79 azaldığı ve 2015 yılında 39026 ton olduğu belirlenmiştir [18]. Yapılan hesaplamalara göre, Türkiye'de kullanılan tarım ilaçları içinde fungisitler \% 40,96'lik bir payla birinci siray1, \% 20,8 ile insektisitler ikinci sıray1, herbisitler ise \% 20,05 ile üçüncü sırayı almıştır. Ayrıca akarisitler \% 4,04'lük ve rodentisitler \% 0,50'lik bir paya sahipken, diğer pestisit grupları \%13,65'lik bir paya sahiptir. Dünya genelinde herbisitlerin en çok kullanılan pestisit türü olduğu, fungusitlerin ise ülkemizden daha az kullanıldığ 1 görülmüş̧ür. Dünya pestisit pazarının büyüklügünün yaklaşık 45 milyar dolar, Türkiye pazarının ise yaklaşık 600 milyon dolar olduğu tahmin edilmektedir [24]. Bu değerlere göre Türkiye Dünya pestisit pazarının \% 1,33'ünü oluşturmaktadır. Türkiye'de ve Dünya'da kullanılan pestisit türlerinin dağılımı Şekil 1'de ve Türkiye'de pestisit türlerinin kullanım miktarları Şekil 2'de gösterilmiştir.

Şekil 2'de görüldüğü gibi üzere Türkiye'de pestisit gruplarının tüketim oranlarında önemli değişiklik insektisit oranında olmuştur. 2007 yılında insektisit kullanımı en büyük paya sahip iken 2008 yılı itibari ile kullanımda bir azalma olmuştur ve takip eden yıllarda artış meydana gelmiştir. Yıllar içerisinde en büyük kullanım payına fungusitler sahip olmuştur.

Ülkemizde tarımsal pestisit kullanımı coğrafi bölgelere göre değerlendirildiğinde en az Karadeniz (\%5) ve Doğu Anadolu (\%1) Bölgelerinde, en çok Akdeniz Bölgesi'nde (\%27) olduğu belirlenmiştir. Marmara, İç Anadolu, Ege ve Güney Doğu Anadolu Bölgelerinde sırasıyla \%18, \%18, $\% 17$ ve \% 14'tür. Gıda ihracatının, polikültür ve enstantif tarımın yapıldığı bölgelerdeki pestisit tüketiminin gelişmiş ülkeler düzeyinde olduğu görülmüştür $[25,26]$. 

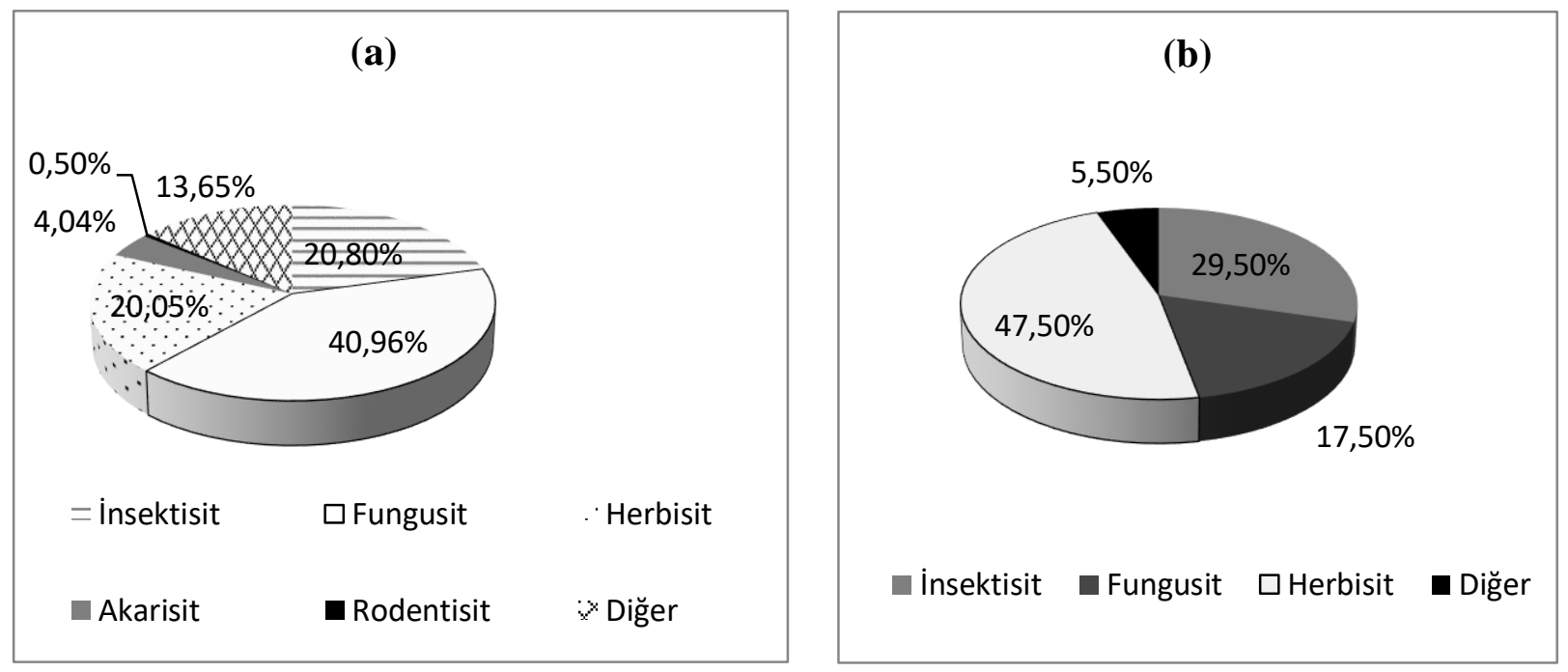

Şekil 1. Türkiye'de (a) ile Dünya'da Kullanılan Pestisit Türlerinin Dağılımı (b) (\%)

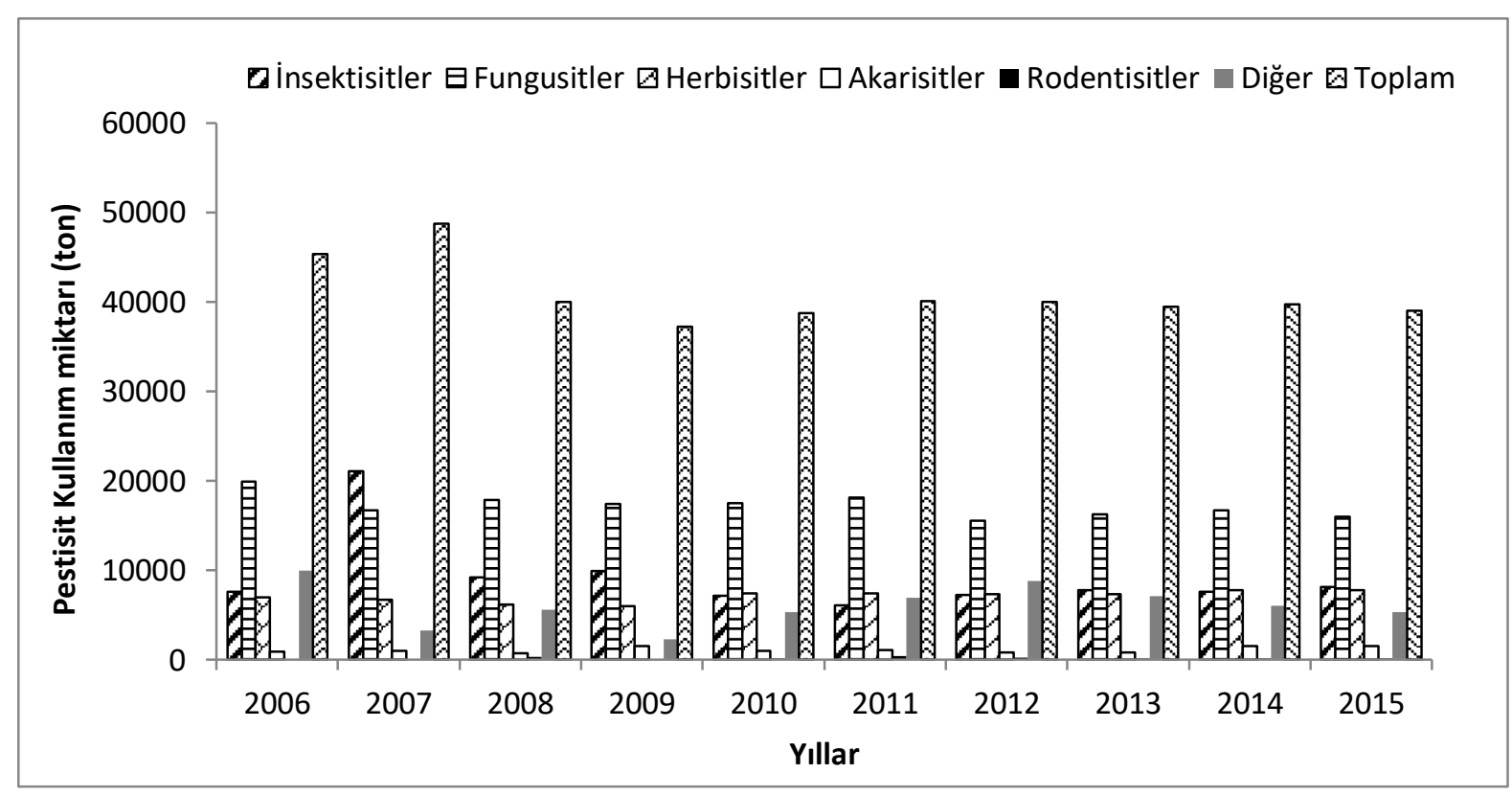

Şekil 2. Türkiye'deki Pestisit Türlerinin Kullanım Miktarları (ton) (TÜiK, 2017)

\subsection{Bursa İli Tarımsal Pestisit Kullanımı}

Ülkemizin önemli bir tarım merkezi olan Bursa İli toplam yüz ölçümü $10.886,38 \mathrm{~km}^{2}$ 'dir ve $340.912,5$ ha (2016 yılı) tarım arazisine sahiptir. Bursa İli bitkisel üretim çeşitlerini meyve, sebze ve tarla bitkileri oluşturmaktadır. Bursa İli bitkisel üretim miktarı Tablo 1'de ve bitkisel ürün çeşidi Tablo 2'de verilmiştir [20].

Tablo 1. Bursa bitkisel üretim miktarı (ton/y1l) [20]

\begin{tabular}{|l|l|l|l|l|l|l|l|l|l|}
\hline & $\mathbf{2 0 0 8}$ & $\mathbf{2 0 0 9}$ & $\mathbf{2 0 1 0}$ & $\mathbf{2 0 1 1}$ & $\mathbf{2 0 1 2}$ & $\mathbf{2 0 1 3}$ & $\mathbf{2 0 1 4}$ & $\mathbf{2 0 1 5}$ & $\mathbf{2 0 1 6}$ \\
\hline Meyve & 522.419 & 596.487 & 542.206 & 549.825 & 591.090 & 639.849 & 622.352 & 593.678 & 576.109 \\
\hline Sebze & 1.312 .542 & 1.358 .282 & 1.220 .201 & 1.715 .410 & 2.037 .107 & 2.065 .515 & 2.231 .379 & 2.731 .066 & 2.338 .604 \\
\hline $\begin{array}{l}\text { Tarla } \\
\text { Bitkileri }\end{array}$ & 1.180 .401 & 1.141 .883 & 2.082 .394 & 1.857 .280 & 1.726 .883 & 2.031 .251 & 2.261 .809 & 2.092 .997 & 2.175 .032 \\
\hline Toplam & 3.015 .362 & 3.096 .652 & 3.844 .801 & 4.122 .515 & 4.355 .080 & 4.736 .615 & 5.115 .540 & 5.417 .741 & 5.089 .745 \\
\hline
\end{tabular}


Tablo 2. Bursa ili bitkisel ürün çeşidi [20]

\begin{tabular}{|l|l|l|}
\hline Meyve & Sebze & Tarla Bitkileri \\
\hline Zeytin & Domates (Sofralık ve salçalık) & Misır (Silajlık, dane, hasıl) \\
\hline Armut & Fasulye (Taze) & Buğday \\
\hline Elma (Starking, grannysmith, golden, diŭ & $\begin{array}{l}\text { Biber (Sivri, salçalık, kapya, } \\
\text { dolmalı) }\end{array}$ & Yonca \\
\hline Ayva & Soğan (Kuru) & Patates \\
\hline Şeftali (Nektarin ve diğer) & Karpuz & Çeltik \\
\hline Çilek & Karnabahar & Ayçiçeği (Çerezlik, yağlık) \\
\hline İncir & Prrasa & Fasulye (Kuru) \\
\hline Kiraz & Bezelye & Fiğ (Adi, yeşil ot, macar) \\
\hline Üzüm (Sofralık-çekirdekli) & Patlıcan & Arpa \\
\hline Ceviz & Kabak (Sakız) & Yulaf (Yeşil ot) \\
\hline Erik & Enginar & Nohut \\
\hline Ahududu & Hiyar (Sofralık) & Şekerpancarı \\
\hline Kestane & Ispanak & Yulaf (Dane) \\
\hline Kavun & Lahana (Beyaz, kırmızı) & Çavdar \\
\hline & Kereviz (Kök) & \\
\hline & Marul (Kıvırcık) & \\
\hline & Barbunya & \\
\hline & Brokoli & \\
\hline & Maydonoz & \\
\hline & & \\
\hline
\end{tabular}

Bursa'da toplam tarımsal üretim en fazla 2015, en düşük, 2008 y1lında görülmektedir. Sebze ve tarla bitkileri üretimi yıllar içerisinde birbirine benzer değişim göstermekte olup bazı yıllarda farklıdır. Meyve üretimi en düşük 2008 yılında, en yüksek 2013 yılında görülmüsstür. Üretimdeki artışın nüfus ve ihracat artışından kaynaklanabileceği düşünülmüştür. İstatistiksel değerlere bakıldığında toplam sebze ve bazı meyve türlerinin (turunçgiller, nar, armut, kiraz vb.) üretimindeki artışın ihracat artışı ile doğru orantılı olarak gerçekleştiği görülmüştür $[18,27]$.

Bursa İli genelinde kullanılan pestisit türleri; fungusit, herbisit, akarisit, insektisidler, kışlık ve yazlık yağlar, nematosidler, mollusidler, rodendisit ve mollusidler ve diğerleridir. Kışlık-yazlık yağlar uçucu ve mineral yağlardan oluşan genellikle böcek ve örümceklerin yumurta bırakmayı engelleyici ve yumurtayı öldürücü etkileri olan pestisitlerdir. $\mathrm{Bu}$ maddeler zirai mücadele ilaçları kontrol yönetmeliğinde kışlık ve yazlık yağlar olarak geçmektedir [28, 29]. En çok kullanılan pestisit türünün fungusit olduğu belirlenmiştir (\%59-\%80). En düşük yüzde ise nematosid ve mollusidlere aittir (\%0$\% 0,007)$. Tablo 3'de Bursa ili y1llık pestisit kullanım miktarları verilmiştir. Yıllık pestisit kullanım miktarları incelendiğinde, 2009-2016 yılları arasında en yüksek fungusit kullanımına 2011 yılında $2.703 .883 \mathrm{~kg}$ ile ulaşılmışken, 2016 yılında $1.564 .745 \mathrm{~kg}$ ile en düşük kullanım miktarı görülmüştür. Fungusit kullanımında dalgalanmalar olsa da genel olarak yıllar içerisinde bir azalma söz konusudur. 2009 yılı kullanım miktarı ile 2016 yılı kullanım miktarı değerlendirildiğinde kullanımda \%18,55'lik bir azalma olduğu sonucuna varılmıştır. Herbisitin 2009-2016 yılları arasındaki kullanım miktarı sabit olmayıp yıllar içerisinde değişimler gözlenmiştir. Maksimum kullanım $157.957 \mathrm{~kg}$ ile 2009 yılında, minimum kullanım ise $50.160 \mathrm{~kg}$ ile 2015 yllında gerçekleşmiştir. Tablo 3'te görüldüğü gibi akarisit kullanımı genel olarak 2009 yılından itibaren 2013 yılına kadar azalmış ve 2013 yılında minimum kullanım miktarı olan $5.925 \mathrm{~kg}$ ulaşmış, 2014 yılından itibaren ise bir artışa geçmiştir. 2009-2016 yılları arasındaki kışlık ve yazlık yağların tüketim miktarları grafiği incelendiğinde 2014 ve 2013 yıllarında tüketimin olmadığı, 2012 yılında $729.826 \mathrm{~kg}$ ile en fazla tüketim gerçekleşmiştir. İnsektisitin 2009-2016 y1lları arasında kullanım miktarı en fazla olan y1 $508.881 \mathrm{~kg}$ ile 2009 y1lı olurken, kullanım giderek azalmıştır ve 2016 yılında $251.307 \mathrm{~kg}$ ile en düşük kullanım miktarına ulaşmıştır. 2009-2016 yıllarındaki rodendisit ve mollusidlerin kullanımına bakıldığında genel olarak kullanımlarının çok düşük olduğu görülmektedir. En fazla kullanım 2011 yılında 85,31 kg ile olmuştur. En düşük kullanım ise 0,004 kg gibi çok düşük bir miktar ile 2012 yılında gerçekleşmiştir. 
Tablo 3. Bursa ili pestisit kullanım miktarları [20]

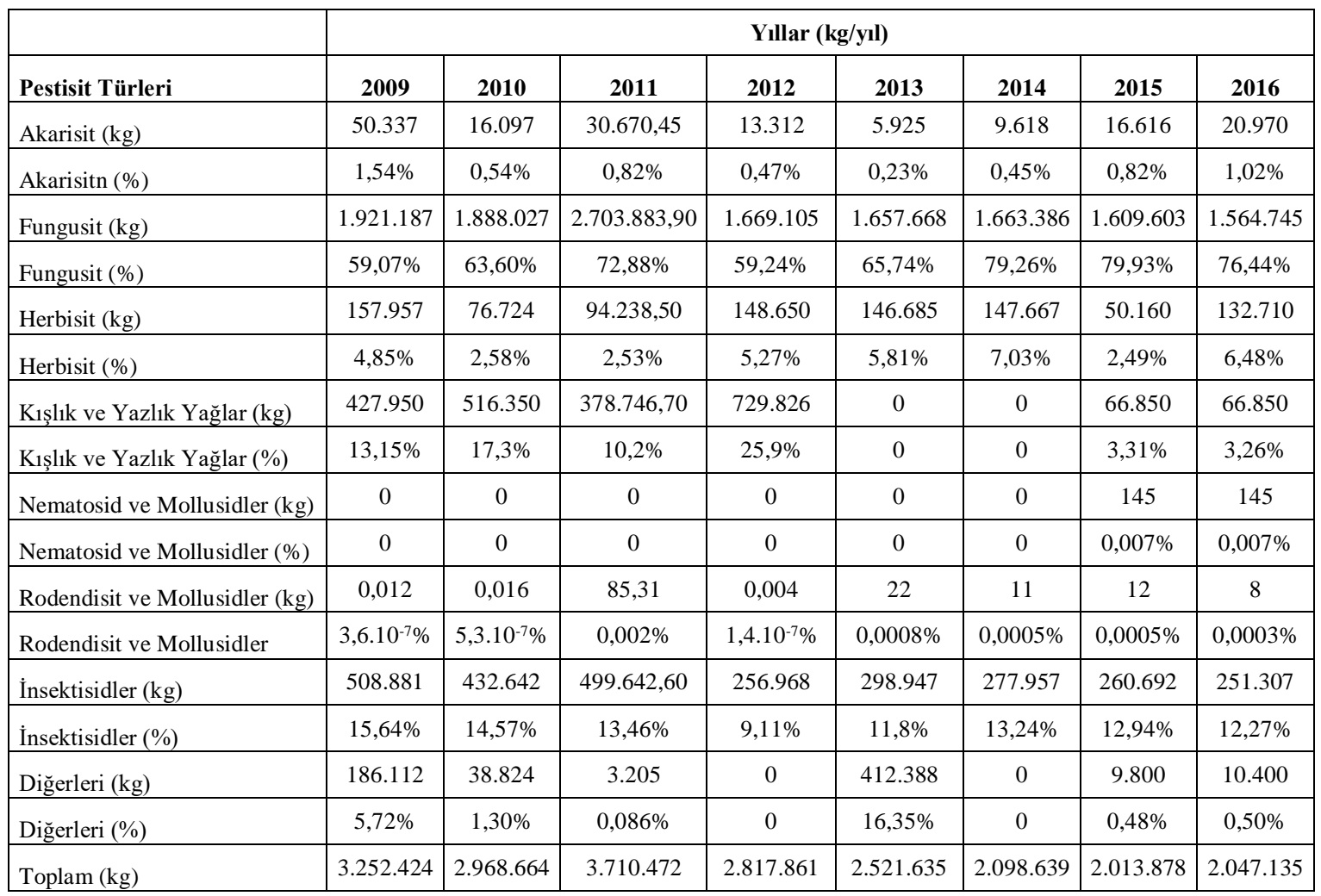

Bursa İli 2009-2016 yıllarına ait bitkisel üretimi ile pestisit türlerinin kullanım miktarları karşılaştırıldığında bitkisel üretim arttığı, pestisit kullanımının azaldığı görülmüştür. Tarımsal ürün çeşidi ile fungusit ve herbisit kullanım miktarları arasındaki istatistiksel ilişkiler değerlendirildiğinde en büyük $\mathrm{r}^{2}$ değerinin meyve üretimi ile fungusit ve herbisit tüketimi arasında olduğu belirlenmiştir. Meyvelerin yıllık ürün miktarının, sebze ve tarla bitkilerine oranla daha az olmasına rağmen daha çok fungusit kullanımına neden olduğu düşünülebilir. En düşük $r^{2}$ değeri ise fungusit-tarla bitkileri arasında bulunmuştur. Kışlık-yazlık yağlar, nemotosit ve mollusit kullanımı ile sebze üretimi arasında en yüksek korelasyonlar bulunmuştur. Tablo 4'te tarımsal ürün çeşidi ile pestisit kullanımı arasındaki korelasyon değerleri gösterilmiştir.

Tablo 4. Tarımsal ürün çeşidi ile pestisit kullanımı arasındaki korelasyon değerleri

\begin{tabular}{|l|l|l|l|l|c|c|c|c|c|}
\hline & & Akarisit & Fungusit & Herbisit & $\begin{array}{c}\text { Kışlık ve } \\
\text { Yazlık } \\
\text { Yağlar }\end{array}$ & $\begin{array}{c}\text { Nematosit ve } \\
\text { Mollusitler }\end{array}$ & $\begin{array}{c}\text { Rodendisit } \\
\text { ve } \\
\text { Mollusidler }\end{array}$ & İnsektisit & Diğerleri \\
\hline $\begin{array}{l}\text { Meyve } \\
\text { Üretimi }\end{array}$ & $\mathrm{r}$ & $-0,3381$ & $-0,5605$ & 0,5547 & $-0,5407$ & $-0,0756$ & $-0,2869$ & 0,1496 & 0,5967 \\
\cline { 2 - 11 } & $\mathrm{r}^{2}$ & 0,1143 & $\mathbf{0 , 3 1 4 1}$ & $\mathbf{0 , 3 0 7 7}$ & $\mathbf{0 , 2 9 2 4}$ & 0,0057 & 0,0823 & 0,0224 & $\mathbf{0 , 3 5 6 1}$ \\
\hline $\begin{array}{l}\text { Sebze } \\
\text { Üretimi }\end{array}$ & $\mathrm{r}$ & $-0,4973$ & $-0,4962$ & $-0,1474$ & $-0,6144$ & 0,6974 & $-0,0356$ & $-0,4573$ & $-0,1683$ \\
\cline { 2 - 11 } & $\mathrm{r}^{2}$ & 0,2473 & 0,2462 & 0,0217 & $\mathbf{0 , 3 7 7 5}$ & $\mathbf{0 , 4 8 6 4}$ & 0,0013 & 0,2092 & 0,0283 \\
\hline $\begin{array}{l}\text { Tarla } \\
\text { Bitkileri } \\
\text { Üretimi }\end{array}$ & $\mathbf{r}$ & $-0,8172$ & $-0,2853$ & $-0,3662$ & $-0,5587$ & 0,3669 & 0,0671 & $-0,4218$ & $-0,2419$ \\
\cline { 2 - 11 } & $\mathbf{r}^{2}$ & $\mathbf{0 , 6 6 7 8}$ & 0,0814 & 0,1341 & $\mathbf{0 , 3 1 2 1}$ & 0,1346 & 0,0045 & 0,1779 & 0,0585 \\
\hline
\end{tabular}

*Koyu renkli $\mathrm{r}^{2}$ değerleri $\mathrm{p} \leq 0,05$

Meyve üretimi ile akarisit, fungusit, nemotosit, mollusit, rodendisit, kışlık ve yazlık yağlar arasındaki korelasyon (r) negatif değerde çıkmıştır. Bu durum meyve üretimi azalsa bile pestisit tüketiminin artabileceğini göstermektedir. Meyve üretimi ile fungusit ve herbisit tüketimi arasında en yüksek $\mathrm{r}^{2}$ değerleri belirlenmiştir. Bu sonuçlar meyve üretimi ile fungusit tüketimi arasında ters orantılı, herbisit tüketimi arasında doğru orantılı bir ilişki olduğunu göstermiştir. 
Sebze üretimi ile nemotosit ve mollusitler arasındaki r değerlerinin en yüksek ve pozitif olduğu, diğer pestisit türleri arasındaki korelasyonların negatif ve daha düşük değerde olduğu görülmektedir. $\mathrm{Bu}$ hesaplamalardan sebze üretimi arrtıkça nematosit ve mollusit kullanımının da arttı̆̆ düşünülebilmektedir.

Tarla bitkileri üretimi ile kullanılan pestisit türleri arasında hesaplanan $r^{2}$ değerleri meyve ve sebze ile olan korelasyonlarında olduğu gibi düşük çıkmıştır. Sadece akarisit kullanımı ile arasında hesaplanan korelasyon değeri negatif ve en yüksek büyüklükte bulunmuştur. Bu değer, tarla bitkileri üretimi arttıkça akarisit kullanımının azaldığını göstermektedir. Tarımsal ürün çeşidi ile pestisit kullanımı arasında hesaplanan korelasyon değerleri arasında en yüksek $r^{2}$ değerine $(0,6678)$ sahip tarla bitkileri üretimi ile akarisit tüketimi arasındaki ilişki Şekil 3’te gösterilmiştir.

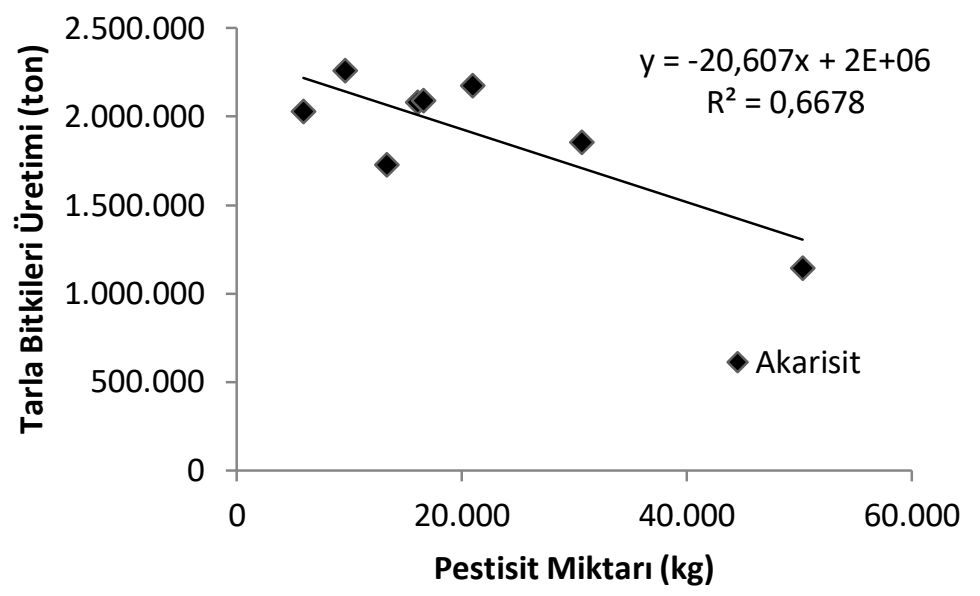

Şekil 3. Bursa İli tarla bitkileri üretimi- akarisit tüketimi ilişkisi

\section{Sonuç ve Öneriler}

$\mathrm{Bu}$ çalışmada, Türkiye ve Dünya'daki pestisit türlerinin kullanım durumu ve Bursa genelindeki pestisitlerin tüketim miktarları incelenmiştir. Ayrıca, Bursa İli bitkisel üretim miktarı ve çeşidi ile pestisit türlerinin kullanımı ilişkilendirilmiştir. Avrupa ülkelerinde en çok satılan pestisit grubu fungusit ve bakterisit olurken, Dünya genelinde ise herbisitler en yüksek, daha sonra insektisitler ve fungusitler kullanılmaktadır. Latin Amerika ve Asya ülkelerinde herbisit ve fungusite ilaveten insektisit te yüksek miktarda kullanılmaktadır. Türkiye'de son 15 yılda pestisit tüketiminin azaldığ1 görülmüş olup, kullanılan tarım ilaçları içinde fungisitler birinci sırayı, insektisitler ikinci sırayı, herbisitler ise üçüncü sırayı almıştır. Ülkemizdeki kullanımın dünya ortalamasından farklı olduğu ve Akdenize kıyısı olan Avrupa ülkelerine benzer olarak Fungusitin en çok kullanıldığı belirlenmiştir.

Bursa'daki pestisit kullanımı, Avrupa ve Türkiye'dekine benzer olduğu ve en çok tüketilen pestisit türünün fungusitler, en düşük kullanımın ise Nematosid ve Mollusidler olduğu belirlenmiştir. Bursa' da tarımsal üretimin artma eğiliminde olduğu görülmüş̧ür ve bu artışın nüfus ve ihracat artışından kaynaklanabileceği düşünülmüştür. Ancak, Bursa genelinde pestisit kullanım miktarları incelendiğinde genel olarak tarımsal pestisit kullanımında azalmaların olduğu görülmüştür. Bursa' da üretilen tarımsal ürün çeşidi ile kullanılan pestisit türleri arasındaki ilişkiler incelendiğinde, akarisit kullanımı ile tarla bitkileri arasında, fungusit ve herbisit kullanımı ile meyve üretimi arasında, Sebze üretimi ile nemotosit, mollusitler, indektisit ve kışlık-yazlık yağlar arasındaki ve diğer pestisit türleri ile meyve üretimi arasındaki ilişkiler yüksek bulunmuştur. Herbisit tüketimi ile meyve üretimi, nemotosit kullanımı ile sebze ve tarla bitkileri üretimi arasındaki korelasyon değerlerinin pozitif olması üretim arttıkça pestisit tüketiminin arttığını göstermiştir. Negatif değerler ise, üretim artsa bile pestisit tüketiminin azalabildiğini göstermiştir. Üretilen meyve miktarının diğer ürünlere nazaran daha az olmasına rağmen daha fazla herbisit ve diğer pestisitlerin kullanımına neden olduğu belirlenmiştir. Bu duruma göre bu 
sonuçlar sadece ürün miktarıla pestisit tüketiminin artmayabileceğini, ürün cinsinin de pestisit tüketimde etkili olabileceğini göstermiştir.

Pestisit kullanımı etkileyen meteorolojik parametreler ve iklim değişikliği, nüfus değişimi, ihracat oranları gibi diğer faktörleri de istatistiksel olarak incelemek gelecekteki kullanım miktarlarını azaltabilmek için yararlı olabilecektir. Kayıt altına alınan verilerin düzenli tutulması, çiftçiler ile iletişimin artırılarak bu konudaki verilerin çoğaltılması gerekmektedir. Veri tabanına göre çalıştırılabilecek yazılımlar kullanılarak pestisit kullanımının optimum olmasının sağlanabileceği düşünülmüştür. Ayrıca, iyi tarım uygulamalarının yapılması, çiftçi eğitim çalışmalarının daha etkili hale getirilmesi ve ilgili Devlet Kurumlarının işbirliği halinde çalışmaları gerekmektedir.

\section{Kaynaklar}

[1] Gill H.K., Garg H. 2014. Pesticide: Environmental impacts and management strategies, in Pesticides-Toxic Effects; Edited by Rijeka, Croatia, Intech, 187-230.

[2] İnan H., Boyraz N. 2002. Konya Çiftçisinin Tarım İlacı Kullanımının Genel Olarak Değerlendirilmesi, Selçuk Üniversitesi Ziraat Fakültesi Dergisi, 16 (30): 88-101.

[3] Başpınar H., Durmuşoğlu E., Yıldırım E.M.. 2010. Türkiye'de Tarım İlaçları Üretim ve Kullanımı, Ziraat Mühendisliği VII., Teknik Kongresi Bildiriler Kitabı, pp 1047-1054, 11-15 Ocak, Ankara, Türkiye.

[4] Tuna R.Y. 2011. Kayseri Çiftçilerinin Pestisitleri Saklama Koşulları ve Güvenli Kullanımı Konusunda Bilgi, Tutum ve Davranışları, Erciyes Üniversitesi Sağlık Bilimleri Enstitüsü, Halk Sağlığı Anabilim Dalı, Doktora tezi, 92 s, Kayseri, Türkiye.

[5] Altıkat A., Turan T., Torun F.E., Bingül Z. 2009. Türkiye'de Pestisit Kullanımı ve Çevreye Olan Etkileri, Atatürk Üniversitesi Ziraat Fakültesi Dergisi, 40 (2): 87-92.

[6] Mahmood I., Imadi S. R., Shazadi K., Gul A., Hakeem K.R. 2016. Plant, Soil and Microbes, in Effects of Pesticides on Environment. Edited by Hakeem, K.R. et al., Springer, International Publishing Switzerland, 253-269.

[7] Garcia F.P., Cortés Ascencio Y.S., Gaytan Oyarzun Y.J., Hernandez A.C., Alavarado P.V. 2012. Pesticides: classification, uses and toxicity. Measures of exposure and genotoxic risks, Journal of Research in Environmental Science and Toxicology, 1 (11): 279-293.

[8] Miller G.T. 2000. Living in the Environment, Concepts, Connections, and Solutions, 16th Edition, 674 s, Belmont, USA.

[9] Rosell G, Quero C, Coll J, Guerrero A. 2008. Biorational insecticides in pest management, Journal of Pesticide Science, 33 (2):103-121.

[10] Sande D., Mullen J., Wetzstein M., Houston J. 2011. Environmental Impacts from Pesticide Use: a Case Study of Soil Fumigation in Florida, Int. J. Environ. Res. Public Health, 8 (12): 4649-4661.

[11] Carriger JF, Rand GM, Gardinali PR, Perry WB, Tompkins MS, Fernandez AM. 2006. Pesticides of potential ecological concern in sediment from South Florida canals: an ecological risk prioritization for aquatic arthropods, Soil and Sediment Contamination, 15 (1): 21-45.

[12] Mostafalou S, Abdollahi M. 2012. Concerns of environmental persistence of pesticides and human chronic diseases, Journal of Clinical and Experimental Pharmacology, 01 (S5), 10-11. DOI: 10.4172/2161-1459.S5-e02.

[13] FAO/WHO, 2015. Pesticide residues in food, Joint FAO/WHO Meeting on Pesticide Residues, FAO and WHO, 627s, Rome.

[14] Pretty J., Bharucha Z.P. 2015. Integrated Pest Management for Sustainable Intensification of Agriculture in Asia and Africa, Insects, 6 (1):152-182.

[15] USEPA, 2018. Integrated Pest Management (IPM) Principles. https://www.epa.gov/safepestcontrol/integrated-pest-management-ipm-principles (Erişim tarihi: 06.08.2018).

[16] Sabur S.A., Molla A.R. 2001. Pesticide use, its impact on crop production and evaluation of IPM technologies in bangladesh, Bangladesh Journal of Agricultural Economics. XXIV, 1 (2): 21-38.

[17] Rahman S., Chima C.D. 2018. Determinants of Pesticide Use in Food Crop Production in Southeastern Nigeria, Agriculture, 8 (35): 1-14.

[18] TÜİK, 2017. Türkiye'de Pestisit Kullanım Miktarları. http://www.tuik.gov.tr (Erişim tarihi: 17.04.2017) 
[19] MINITAB, 2017. Minitab Statistical Program Version 17.

[20] Anonim, 2016. Bursa İl Gıda, Tarım ve Hayvancılık Müdürlüğü, 2008-2016 Faaliyet Raporları.

[21] FAO, 2017. Food and Agriculture Data for Over 245 Countries. http://www.fao.org/faostat/en/\#home (Erişim tarihi: 03.01.2017).

[22] EU, 2018. Member of European Countries Statics. http://ec.europa.eu/eurostat/statisticsexplained/ (Erişim tarihi: 28.03.2018).

[23] De A., Bose R., Kumar A., Mozumdar S. 2014. Targeted Delivery of Pesticides Using Biodegradable Polymeric Nanoparticles, Springer, 99s, New Delhi Heidelberg New York Dordrecht London.

[24] Kaymak S., Serim A.T. 2015. Pestisit Sektöründe Araştırma ve Geliştirme, Meyve Bilimi, 2 (1): 27-34.

[25] Durmuşoğlu E., Tiryaki O., Canhilal R. 2010. Türkiye'de Pestisit Kullanımı, Kalıntı ve Dayanıklılık Sorunları, VII. Türkiye Ziraat Mühendisliği Teknik Kongresi, TMMOB Ziraat Mühendisleri Odas1, Bildiriler Kitab1, s 589-607, 11-15 Ocak, Ankara

[26] Burçak A. 2014. Gıda, Tarım ve Hayvancılık Bakanlı̆̆ı, Bitki Sağlığı Araştırma Daire Başkanlığı, İlaç, Alet ve Toksikoloji Araştırmaları Çalışma Grubu Sunumu. https://www.tarimorman.gov.tr/TAGEM/Belgeler/SUNULAR/\%C4\%B0la\%C3\%A7,\%20Alet\%2 0ve\%20Toksikoloji\%20Ara\%C5\%9Ft\%C4\%B1rma\%20\%C3\%87al\%C4\%B1\%C5\%9Fmalar\%C 4\%B1_Dr.\%20A.Alev\%20Bur\%C3\%A7ak.pdf (Erişim tarihi: 05.11.2018).

[27] Demirci G. 2017. Türkiye'de ve Dünya'da Kullanılan Pestisit Türlerinin Araştırılması, Uludăg Üniversitesi, Mühendislik Fakültesi, Çevre Mühendisliği Bölümü Lisans Tezi, 90s, Bursa.

[28] İmrek B., Güven H., Erler F., Tosun H.Ş. 2017. Bazı Bitki Uçucu Yağlarının Armut Psillidi [Cacopsylla pyri (L.) (Hemiptera: Psyllidae)]'nin Kışlık-Formuna Karşı Yumurta Bırakmayı Engelleyici ve Ovisidal Etkileri, Harran Tarım ve Gida Bilimleri Dergisi, 21 (3): 259-265.

[29] Anonim, 1995. Tarım ve Köyişleri Bakanlığı, Zirai Mücadele İlaçları Kontrol Yönetmeliği, 22/06/1995 Tarihli ve 22321Sayılı Resmi Gazete, 13s. Ankara. 